\title{
STRATEGI MENINGKATKAN JUMLAH PENGUNJUNG WISATA TAMAN BUAYA TANJUNG PASIR
}

\author{
Antonius Dwinarendra ${ }^{1)}$, Parino Rahardjo ${ }^{2)}$, Priyendiswara Agustina Bela ${ }^{3)}$ \\ 1)Program Studi S1 PWK, Fakultas Teknik, Universitas Tarumanagara, motorgusi88@gmail.com \\ 2) Program Studi S1 PWK, Fakultas Teknik, Universitas Tarumanagara, parinor19@gmail.com \\ ${ }^{3)}$ Program Studi S1 PWK, Fakultas Teknik, Universitas Tarumanagara, hedy.agustina@gmail.com
}

\begin{abstract}
Abstrak
Taman Wisata Buaya Tanjung Pasir memiliki luas lahan 5 hektare. Taman buaya ini berada di Kawasan Wisata Tanjung Pasir, sebagai destinasi wisata di Kabupaten Tangerang dan sekitarnya. Taman Buaya ini telah beroperasi sejak 2005 yang dimiliki oleh Lukman Arifin. Taman buaya ini merupakan satu - satunya taman hiburan fauna dan penangkaran khususnya buaya yang ada di Tangerang. Taman buaya ini diharapkan menjadi salah satu ikon baru di Kawasan Wisata Tanjung Pasir dan menjadi taman hiburan yang edukatif. Pada saat ini terdapat lebih dari 400 ekor buaya dari usia baru menetas sampai 70 tahun dan di taman buaya ini memiliki koleksi buaya albino yang terbilang langka. Selain melihat buaya di taman buaya ini juga dapat memberi makan buaya. Dahulu taman buaya ini memiliki berbagai pertunjukan pawang buaya, menjual pernak - pernik buaya, namun kini sudah berhenti karena sepinya pengunjung. Penelitian ini memiliki tujuan untuk mengetahui potensi dan masalah yang ada di Taman Buaya Tanjung Pasir yang berdampak pada sepinya pengunjung. Pengumpulan data dilakukan dengan cara survey lapangan, sebar kuisioner, wawancara, dokumentasi dan studi literature. Dari hasil analisis yang dilakukan seperti analisis lokasi dan tapak, analisis benchmark, analisis persepsi pengunjung dan kebijakan, dihasilkan usulan strategi seperti dari mulai perbaikan fisik, perbaikan menejemen, dan usulan promosi taman wisata. Sehingga pengunjung merasa tertarik untuk berkunjung.
\end{abstract}

\section{Kata Kunci: Pengunjung; Strategi; Taman Buaya}

\begin{abstract}
Crocodile Tourism Park has a land area of 5 hectares. This crocodile park is located in Tanjung Pasir tourist area, as a tourist destination in and around Kabupaten Tangerang. This crocodile park has been operating since 2005 owned by Lukman Arifin. This crocodile park is the only theme park of fauna and breeding, especially crocodile in Tangerang. This crocodile park is expected to be one of the new icons in Tanjung Pasir tourism area and become an educative amusement park. At the moment there are more than 400 crocodiles of new age hatch up to 70 years and in this crocodile park has a rare collection of albino crocodiles. In addition to seeing crocodiles in this crocodile park can also feed crocodiles. Once this crocodile park has various performances of crocodile, selling the knacks, but now stopped because of the visitors. This research aims to determine the potential and problems of the Tanjung Pasir Crocodile Park, which has an impact on visitors. Data collection is done by field survey, questionnaire scatter, interview, documentation and literature study. From analysis results conducted such as site and site analysis, benchmark analysis, visitor perception analysis and policy, resulted in strategy proposals such as from the start of physical repair, improvement of management, and proposed promotion of tourist parks. So visitors feel interested to visit.
\end{abstract}

Keywords: crocodile park; strategy; visitors 


\section{PENDAHULUAN}

\section{Latar Belakang}

Tanjung Pasir juga memiliki satu wisata unik lainnya yang berbeda dari kawasan wisata pantai lainnya yaitu Taman Wisata Buaya. Taman Wisata Buaya Tanjung Pasir berada di Kecamatan Teluknaga dengan luas lahan 5 hektare memiliki beberapa kandang penangkaran. Tempat dimiliki oleh Lukman Arifin, berawal dari memiliki buaya tahun 1960an sang pemilik memutuskan untuk membuka Taman Wisata Buaya pada tahun 1992 di Jakarta tepatnya di Pluit, karena antusias yang besar sang pemilik membuka kembali wisata taman buaya di Bekasi tahun 2002 dan yang terakhir adalah di Tanjung Pasir Ini.

Kini Taman Wisata Buaya Tanjung Pasir dikelola oleh sang anak Bapak Sugiarta Arifin. Dahulu wisata taman buaya di Tanjung Pasir memiliki serangkaian acara untuk menarik pengunjung, tidak hanya untuk sekedar melihat buaya tetapi juga ada pertunjukan seperti musik dangdut, debus Banten, dan atraksi buaya yang dilakukan oleh pawang tentu oleh ahlinya, seperti di tempat wisata lainnya juga yang dimana tidak hanya dari segi pertunjukan, dahulu pihak pengelola dan masyarakat sekitar membuka toko-toko kerajinan tas dari kulit buaya dan kios serta saung-saung untuk berjualan makanan untuk pengunjung dapat bersantai. Kasiat buaya di Taman Wisata Buaya Tanjung Pasir ini ketika sudah mati oleh pengelola dijadikan berbagai macam kegunaan terutama dalam menyembuhkan berbagai penyakit mulai dari penyakit kulit, stamina pria dan obat sakit organ dalam lainnya. Kemudian seiring dengan banyaknya pengunjung, pemilik dibantu oleh pemerintah kabupaten setempat untuk mengembangkan penangkarannya dengan memberikan ijin untuk dijadikan tempat wisata baru dan mulai beroperasi secara terbuka pada tahun 2005.

Taman Wisata Buaya ini terletak di pesisir utara di wilayah Kabupaten Tangerang. Taman buaya Tanjung Pasir yang terletak dekat Bandara Internasional Soekarno - Hatta ini merupakan sebuah tempat penangkaran buaya berskala besar tepatnya berlokasi di Jl. Raya Tanjung Pasir, tepatnya di Jl. Raya Tanjung Pasir KM 29 Kabupaten Tangerang. Taman Wisata Buaya ini dinilai bisa menjadi tempat wisata yang edukatif selain ingin datang ke pantai Tanjung Pasir. Harga tiket masuknya pun cukup murah, untuk dewasa sebesar Rp. 8000,00 dan anak-anak Rp. 4000,00. Di Taman Wisata Buaya ini terdapat lebih dari 500 ekor buaya dari berbagai jenis, dan usia bisa mencapai 40 tahun. Jam Operasional di Taman Wisata Buaya Tanjung Pasir mulai pukul 08:00 Wib - 18:00. Kini 14 tahun dari awal didirikannya Taman Wisata Buaya Tanjung Pasir justru mengalami penurunan pengunjung dan Taman Wisata Buaya ini sudah dianggap tidak layak karena tidak kurangnya perhatian dari pihak pengelola.

\section{Rumusan Masalah}

Berdasarkan dari latar belakang diatas, berikut poin - poin penting yang dijadikan rumusan masalah dalam makalah ini:

a. Kurangnya fasilitas dan kondisi kandang yang sudah tidak terawat dan berfungsi dengan baik berpengaruh pada jumlah pengunjung

b. Tidak adanya kegiatan acara, pertunjukan atraksi dan toko yang menjual souvenir untuk menghibur pengunjung dan untuk cinderamata sehingga pengungunjung terkesan dan ingin datang lagi.

c. Tidak adanya strategi pemasaran yang unik dari taman wisata itu sendiri untuk meningkatkan jumlah pengunjung

\section{Tujuan}

Tujuan penelitian ini untuk mengetahui masalah dan potensi yang dimiliki Taman Buaya Tanjung Pasir, yang menyebabkan sepinya pengunjung, serta memberikan usulan strategi untuk meningkatkan pengunjung sesuai dengan keinginan konsumen dan melihat dari objek studi lain yang serupa. 


\section{KAJIAN LITERATUR}

\section{Taman Wisata}

Taman Wisata adalah kawasan hutan konservasi yang bisa dimanfaatkan untuk kegiatan pariwisata dan rekreasi. Kegiatan pariwisata yang dilakukan didalam hutan wisata alam tidak boleh berlawanan dengan prinsip konservasi dan perlindungan alam. Wisata taman buaya dapat dikatakan sebagai wisata Aquaculture. Di Indonesia buaya sudah lama dimanfaatkan oleh sebagian masyarakat dalam beberapa aspek kehidupan, seperti sebagai sumber protein hewani, obat kuat, ornamen dan sumber perekonomian dari kulitnya yang berharga tinggi serta dijadikan hewan yang dapat mengedukasi dan atraksi pertunjukan.

\section{Crocodile Farming}

Crocodile Farming adalah program budidaya buaya dari telur hingga menghasilkan sesuatu dari buaya tersebut seperti dagingnya, kulitnya, hingga kukunya. Disisi lain dalam sebuah proses crocodile farming tentu peternak/pelaku usaha memiliki kandang dan tempat yang menyerupai habitat aslinya, hal ini dapat dimanfaatkan juga untuk dijadikan tempat edukasi mengenai buaya dalam bentuk usaha wisata taman buaya. Kini industri buaya sangat diminati, mengingat permintaan kulit buaya, daging, serta kuku buaya yang tinggi untuk dijadikan bermacam-macam barang jadi seperti tas dari kulit buaya, ikat pinggang, sepatu, dan untuk restaurant yang menjual daging buaya, hingga kasiat dari kuku dan gigi buaya untuk penyakit kulit yang dihasilkan dari minyak nya.

Dahulu perburuan buaya di habitat aslinya sangatlah tinggi karena hasil dari industri sangatlah besar, contoh untuk 1 kulit buaya kecil harganya dapat mencapai Rp.700.000 sampai Rp.1.000.000. Namun, seiring dengan perkembangan zaman, perburuan buaya yang illegal tersebut berkurang dengan adanya program crocodile farming ini. Sehingga industry buaya dapat berjalan dengan baik dan menguntungkan tanpa harus menghancurkan ekosistem buaya di habitat aslinya.

\section{Wisata Taman Hiburan Buaya}

Salah satu karakteristik paling penting dari pertanian buaya (crocodile farming) adalah bahwa mereka dapat menjadi daya tarik untuk tujuan wisata. Selama aplikasi pertanian, sebuah peternakan yang dirancang untuk pengunjung akan dengan mudah mendapat manfaat dari pendapatan ekonomi selain kulit dan daging buaya. Biaya masuk dan penjualan toko suvenir serta restoran terintegrasi sangat menguntungkan petani dengan pendapatan sampingan. Aplikasi jenis ini tersebar luas di seluruh Asia. Petani buaya Asia mengintegrasikan tanda-tanda eco-park di sebagian besar lahan pertanian yang lebih dekat ke kota. Taman-taman ini menawarkan pertunjukan buaya, tamasya, penjualan toko cenderamata, dan objek wisata serupa yang semuanya terkait dengan buaya sebagai penghasilan sampingan dari bertani. Beberapa dari mereka bahkan memiliki hewan lain membuat peternakan menjadi kebun binatang kecil untuk dikunjungi wisatawan. Mayoritas produsen menerapkan desain taman lingkungan dalam investasi mereka untuk keuntungan yang lebih besar dari pertanian buaya. Jenis desain ini lebih disukai untuk negara-negara wisata.

\section{Faktor Sukses Taman Wisata Hiburan (Kaplan, 2002)}

Taman hiburan atau taman bermain adalah tempat dengan daya tarik yang terdiri atas wahana permainan atau bahkan pertunjukan. Biasanya taman hiburan memiliki sejumlah jenis wahana permainan yang berbeda-beda, toko, restoran, dan gerai (outlet) serta hiburan lainnya. Industri taman hiburan, sebagai segmen yang didefinisikan dengan jelas, relatif baru. Banyak Taman tema historis yang dimiliki keluarga dan unit tunggal yang dilayani populasi perumahan tertentu. Hari ini, kelompok operator yang muncul dan operasi dan desain taman hiburan menjadi semakin lebih canggih. Sebuah taman dapat didefinisikan sebagai gated, hiburan atraksi dengan berbagai wahana dan menunjukkan yang berbasis di sekitar tema atau jumlah tema. 
Ada beberapa aspek yang perlu diliat sebagai suatu taman wisata hiburan. Berikut adalah beberapa aspek yang membuat sebuah wisata taman hiburan sukses:

a. Penelitian: penelitian dimuka memberikan indikasi yang jelas tentang konsep yang relevan dan permintaan dalam pasar. Penelitian yang berkelanjutan menunjukkan cara-cara untuk meningkatkan Taman, memperluas Taman dan meningkatkan daya tarik pasar. Penelitian akan memberikan dasar untuk mengembangkan Taman ukuran yang tepat untuk pasar ukuran yang tepat pada anggaran ukuran yang tepat.

b. Situs: untuk pengembangan sebuah taman hiburan situs datar adalah lebih baik. Biaya modal dari groundworks pada situs miring atau situs bergelombang cepat menjadi penghalang dan sebuah situs datar memungkinkan untuk padat mempopulasikan dengan atraksi tanpa ' kehilangan ' terlalu banyak situs di daerah tak terbangun.

c. Pasar: pasar untuk Taman harus jelas didefinisikan dan harus ada banyak itu. Taman sukses umumnya menarik mayoritas pengunjung mereka dari dalam waktu dua jam berkendara. Oleh karena itu, Taman bergantung pada kedekatan dengan (dan akses ke) pasar ini.

d. Produk + Visi: kekayaan intelektual (IP) penyedia yang semakin penting bagi keberhasilan sebuah taman hiburan. Sebuah merek terkenal akan menambah daya tarik langsung dari Taman dan target pasar. Selain itu, perpaduan atraksi di dalam taman hiburan ini juga harus seimbang dalam hal pasar, sub segmen di dalamnya (seperti kelompok usia yang berbeda), dan juga dengan pandangan untuk mengelola waktu antrian pada masing-masing komponen.

e. Harga: Harga yang berhasil didasarkan pada comparables lokal dan internasional. Harga lokal untuk hiburan akan memberikan pandangan untuk berapa banyak pasar yang digunakan untuk membayar ' jam hiburan ', harga internasional memberikan wawasan tentang perbedaan yang dibebankan oleh berbagai merek dan tujuan dan apa premi mungkin relevan. Penetapan harga lebih penting karena merupakan salah satu alat terpenting yang digunakan dalam mengelola waktu puncak dan musim.

f. Management: Manajemen yang berpengalaman adalah mesin dari industri Taman Hiburan, khususnya di mana pasar dewasa dan kompetitif memeras margin keuntungan, manajemen yang kuat sangat penting.

g. Marketing: Bisnis taman hiburan sangat sensitif pemasaran, karena produk bersaing dengan banyak bentuk lain dari rekreasi dan hiburan. Di pasar baru, pemasaran yang berat diperlukan untuk membangun identitas dan membangun kesadaran akan produk, sementara di pasar yang matang ada kebutuhan yang kuat untuk terus menerus menginduksi kunjungan berulang.

h. Reinvestment: Reinvestment sangat penting untuk tema taman. Dengan mayoritas pengunjung yang datang dari dalam waktu dua jam berkendara, Taman Hiburan harus menawarkan sesuatu yang baru secara teratur untuk memastikan kunjungan berulang dari pasar penduduk. Untuk melakukannya, reinvestasi dalam wahana baru dan menunjukkan adalah kuncinya. Dari penelitian kami, kami tahu bahwa investasi dalam sebuah atraksi baru (jika ditargetkan dengan baik) terbayar langsung di nomor kehadiran yang lebih tinggi.

\section{Pengunjung}

Definisi pengunjung dapat dikatakan tidak jauh berbedanya dengan wisatawan kita dapat melihat perbedaannya dari jangka waktu ia berpariwisata. Bilamana seseorang melakukan kegiatan pariwisata dengan kurun waktu kurang dari 24 Jam maka dari itu ia tidak dapat kita katakan sebagai tourist dikarenakan dia hanya melakukan kunjungan tanpa memerlukan akomodasi dan lain-lainnya, maka dari hal itu ia dapat kita katakan sebagai pengunjung.

\section{Strategi}

Strategi adalah suatu hal untuk mencapai tujuan, dimana isu kritis atau faktor keberhasilan dapat dilihat, serta keputusan stratejik bertujuan untuk membuat dampak yang besar serta jangka panjang keberhasilan tersebut. Strategi pada umumnya adalah berupa rencana (plan) 
dan manajemen yang dipikirkan matang-matang (management) untuk mencapai suatu tujuan. Tetapi, untuk mencapai tujuan tersebut, strategi tidak berfungsi begitu saja tanpa ada perbuatan yang konkrit untuk merealisasikan strategi itu dan mencapai keberhasilan

\section{Pemasaran}

Pemasaran merupakan kegiatan untuk terjadinya proses transaksi antara pemilik jasa/barang dengan konsumen. Pemasaran pariwisata sebagai suatu bentuk usaha untuk memudahkan terjadinya transaksi pariwisata bagi pemilik atau pengelola kepada masyarakat. Dalam hal ini, pemasaran juga dipandang sebagai proses manajemen suatu tempat wisata untuk mempengaruhi wisatawan supaya datang ke tempat wisata tersebut.

\section{METODE}

Dalam penelitian ini terdapat dua jenis data, yaitu data primer dan data sekunder, antara lain sebagai berikut.

a. Data Primer

Data primer merupakan data yang didapat langsung dari objek penelitian, bukan dari sumber lain. Pengumpulan data primer yaitu sebagai berikut:

1. Survey lokasi kondisi fisik eksisting Wisata Taman Buaya Tanjung Pasir.

2. Dokumentasi dan data Wisata Taman Buaya Tanjung Pasir

3. Melakukan wawancara kepada pengunjung Wisata Taman Buaya Tanjung Pasir dengan kuesioner.

Pengumpulan data dilakukan agar mendapatkan data mengenai objek studi. Dalam hal ini adalah Kawasan Wisata Tanjung Pasir, maka dari itu diperlukan metode pengumpulan data yang sesuai dengan kebutuhan.

b. Data Sekunder

Data sekunder merupakan data yang didapatkan dari berbagai sumber lain yang relevan seperti artikel, buku, serta sumber dari internet yang dapat dipertanggungjawabkan. Data sekunder yang diperoleh adalah sebagai berikut:

1. Data lokasi dan fasilitas Taman Buaya Tanjung Pasir

2. Peraturan kebijakan yang terkait dengan Kawasan Wisata Tanjung Pasir. 58

3. Internet, Studi literature, skripsi, dll.

4. Studi kasus lain / Benchmarking

Pengumpulan data dilakukan agar mendapatkan data mengenai objek studi. Dalam hal ini adalah Wisata Taman Buaya Tanjung Pasir, maka dari itu diperlukan metode pengumpulan data yang sesuai dengan kebutuhan. Teknik pengumpulan data dapat dilakukan dengan cara sebagai berikut:

1. Teknik Pengumpulan Data Primer

a. Survey Lapangan; Survey lapangan dilakukan untuk mengamati secara langsung pada objek penelitian yang dilakukan oleh peneliti, khusus untuk data yang tidak bisa didapatkan dengan cara sekunder. Survei lapangan ini bertujuan untuk mengetahui kondisi lapangan terkini dari objek yang akan diteliti.

b. Wawancara; Wawancara akan dilakukan dengan pihak terkait yaitu kepada pelaku usaha.

c. Kuisioner; Kuisioner akan dilakukan kepada pengunjung di taman wisata buaya tanjung pasir dan pengunjung yang terdapat di kawasan wisata tanjung pasir. Untuk mengetahui sampel yang akan dibagikan kuisioner penulis menggunakan rumus slovin.

2. Teknik Pengumpulan Data Sekunder

Data ini diperoleh dari sumber lain terkait objek studi. Dalam penelitian ini data sekunder diperoleh dari berbagai sumber yang relevan seperti studi literatur, skripsi/tesis, internet, dll 
Penelitian objek studi Taman Buaya Tanjung Pasir yang memiliki luas $5 \mathrm{Ha}$ ini terbagi menjadi dua teknik pengumpulan data yaitu, primer dan sekunder. Data primer didapatkan dari hasil wawancara dengan pihak pengelola, kuisioner pengujung, survey lapangan, dokumentasi dll. Sedangkan data sekunder berasal dari internet, pemerintah, dan benchmarking. Pada penelitian ini penulis melakukan 6 analisia untuk mencapai tujuan dari penelitian ini.

a. Analisis Kebijakan

b. Analisis Lokasi; Analisis ini bertujuan untuk mengetahui potensi masalah lokasi serta karakteristik lokasi yang ada di sekitar Wisata Taman Buaya Tanjung Pasir dan juga kita dapat mengetahui aksesibilitas, transportasi umum, serta penggunaan lahan sekitar.

c. Analisis Tapak; Analisis ini bertujuan untuk mengetahui konsidi eksisting bangunan dan fasilitas yang tersedia di Taman Buaya Tanjung Pasir dan juga dapat mengetahui apa yang harus dilakukan guna meningkatkan pengunjung.

d. Analisis Persepsi dan Preferensi Pengunjung; Analisis ini bertujuan untuk memperoleh karakteristik pengunjung dan kunjungan serta tanggapan dan penilaian pengunjung terhadap kondisi kawasan dan kualitas di Taman Buaya Tanjung Pasir. Metode yang digunakan ialah metode deskriptif dan diagram cartesius.

e. Analisis Benchmark; Analisis ini bertujuan agar kita dapat menentukan taman wisata yang ideal dengan membandingkan dengan taman wisata yang sejenis serta dapat menentukan konsep taman wisata.

f. Analisis Strategi Meningkatkan Jumlah Pengunjung; Analisis ini bertujuan untuk mengetahui cara apa yang akan dilakukan penulis untuk meningkatkan jumlah pengunjung, dilihat dari kesimpulan berbagai analisis yang sudah di lakukan.

\section{DISKUSI DAN HASIL}

\section{Profil Wisata Taman Buaya Tanjung Pasir}

Jumlah buaya yang ada di Wisata Taman Buaya Tanjung Pasir mencapai 500 ekor dari umur yang berbeda juga. Terdapat 7 kandang yang terdiri dari 3 kandang besar dan 4 kandang karantina. Setelah memasuki gerbang, para pengunjung akan melewati loket masuk menuju kandang buaya, kemudian berjalan sejauh 100 meter untuk sampai ke kandang buaya dengan melewati tempat kantin-kantin yang sudah tidak terpakai karena tidak ada yang berjualan. Terdapat fasilitas umum lainnya seperti mushola dan saung tempat bersantai untuk melihat buaya atau berkumpul bersama keluarga. Sayangnya di taman buaya ini kurang fasilitas toilet yang membuat pengunjung susah.

\section{Kebijakan Pemerintah}

Kawasan Wisata Tanjung Pasir dibentuk berdasarkan Peraturan Derah Kabupaten Tangerang nomor 7 tahun 2007 tentang Pembentukan Pemerintahan Desa di lingkungan Kabupaten Tangerang. Menurut Peta Rencana Tata Ruang Wilayah Kabupaten Tangerang tahun 2011-2031, Taman Buaya Tanjung Pasir berada di kawasan permukiman kepadatan sedang.

\section{Lokasi}

Terdapat 2 rute yang dapat ditempuh untuk sampai lokasi wisata. Pertama, Apabila kita dari arah Jakarta kita dapat menggunakan jalan tol menuju arah bandara sekaligus juga menghubungkan akses ke Bandara Internasional Soekarno-Hatta. Dari Jl Tol Airport Prof. Sedyatmo tersebut kita dapat exit Tol Kamal 1, kemudian ke Jl. Kapuk Kamal, Jl. Raya Dadap, Jl. Raya Kosambi, Jl. Salembaran kemudian ke Jl. Tanjung Pasir Raya. Dari Jakarta waktu tempuh yang dibutuhkan sekitar 1 jam 10 menit dengan jarak 31,4 km. Kedua, dari arah Tangerang sendiri kita dapat memulai dari Tol Tangerang - Jakarta kemudian keluar tol Tangerang, melewati jalan $\mathrm{MH}$. Thamrin, Jl. Jend Sudirman, Pembangunan 3 kemudian menuju ke Jl Marsekal Surya Dharma Baru, Jl. Kampung Melayu itu berada di belakang Bandara Internasional Soekarno-Hatta setelah itu menuju JL Raya Tanjung Pasir. Waktu tempuh yang diperlukan 1 jam 5 menit dengan jarak 27,6 km. Rute kedua ini dinilai lebih cepat untuk sampai ke objek studi 
dikarenakan melewati jalan perkampungan dan pada hari kerja rute ini hanya sedikit mengalami kemacetan dibandingkan rute pertama yang mana kemacetan terjadi menuju arah Bandara International Soekarno-Hatta.

\section{Tapak}

Melihat dari kondisi yang ada di lapangan hampir seluruhnya sarana atau fasilitas yang ada sudah tidak terawat bahkan sampai rusak. Seperti kandang buaya besar besi-besi nya sudah karatan dan banyak yang patah sehingga membuat ketakutan bagi pengunjung. Selain itu juga seperti tempat makan atau kios kantin sudah banyak yang rusak seperti atap bocor dan roboh, sehingga kini sudah tidak ada yang menyewa kios tersebut. Kemudian untuk fasilitas lainnya seperti saung, toilet, mushola, hingga loket sudah tidak terawat, kotor, bahkan seperti loket masuk saja sudah tidak terpakai, alhasil pihak pengelola memberikan tiket di pinggi jalan dekat loket. Untuk lahan parkir masih cukup baik dan dapat terpakai hanya saja tidak adanya petugas parkir untuk menjaga kendaraan. Prasarana seperti air bersih di lokasi objek studi juga tidak mengaliri dengan baik, seperti di toilet air mengalir kecil dan berkeruh, menurut pihak pengelola air keruh dikarenakan sekitar lokasi banyak tambak ikan. Prasarana listrik di taman buaya ini juga belum sepenuhnya mengaliri, walaupun taman buaya ini tutup pada pukul 6 sore namun penerangan di toilet dan mushola masih sangat kurang bahkan di toilet tidak ada lampu jadi sumber penerangan hanya melalui ventilasi diatas pintu.

\section{Benchmark}

Objek wisata dengan konsep corocodile park and farming yang mirip dengan objek studi adalah Davao Crocodile Park di Kota Davao, Filipina dan Pattaya Crocodile Farm and Stone Park di Kota Pattaya, Thailand.

Tabel 1. Perbandingan kedua Benchmark

\begin{tabular}{lll}
\hline \multicolumn{1}{c}{ Davao Crocodile Park Phillipines } & \multicolumn{1}{c}{ Pattaya Crocodile Farm Thailand } \\
\hline $\begin{array}{l}\text { Mengembangbiakan buaya dari telur hingga } \\
\text { dewasa, jadi lebih ke budidaya buaya. }\end{array}$ & $\begin{array}{l}\text { Memelihara buaya yang berkualitas bagus } \\
\text { dan terlatih }\end{array}$ \\
\hline $\begin{array}{l}\text { Menghasilkan produk yang dikenal dari } \\
\text { bahan dasar buaya, mulai dari olahan kulit, } \\
\text { kuku, empedu, hingga telur buaya }\end{array}$ & $\begin{array}{l}\text { Membuat pertunjukan buaya yang besar } \\
\text { dan megah dengan buaya yang terlatih dan } \\
\text { pawang yang profesional }\end{array}$ \\
\hline $\begin{array}{l}\text { Menjadikan produk olahan buaya sebagai } \\
\text { penghasil utama. }\end{array}$ & $\begin{array}{l}\text { Menjadikan atraksi atau pertunjukan buaya } \\
\text { sebagai acara utama, walaupun ada acara } \\
\text { binatang lain namun tidak sebesar }\end{array}$ \\
$\begin{array}{l}\text { Pasar yang menjadi tujuan utama untuk } \\
\text { produk nya adalah para pemiliki perusahaan } \\
\text { atau pabrik yang bergerak dibidang tekstil } \\
\text { dari bahan dasar kulit buaya. }\end{array}$ & $\begin{array}{l}\text { Pasar yang menjadi tujuan utama adalah } \\
\text { turis dan } \\
\text { rombongan/gathering dari kantor serta filed } \\
\text { trip anak sekolah. }\end{array}$ \\
\hline
\end{tabular}

Sumber : Olahan Penulis, 2020

Kedua benchmark yang serupa dengan Wisata Taman Buaya Tanjung Pasir memiliki konsep yang hampir sama yaitu konsep crocodile farming dan hiburan dan tentu dapat dijadikan contoh untuk kajian objek studi Taman Buaya Tanjung Pasir dengan tujuan memperbaiki dan mengetahui kelebihan dan kekurangan objek studi.

\section{Persepsi Pengunjung}

Menurut tanggapan pengunjung dari hasil kuisioner bahwa terdapat beberapa fasilitas dan kondisi fisik yang harus di lakukan perbaikan prioritas. Fasilitas seperti toilet, mushola, loket, kandang, saung, kantin dan juga kurangnya promosi serta edukasi kepada pengunjung. 


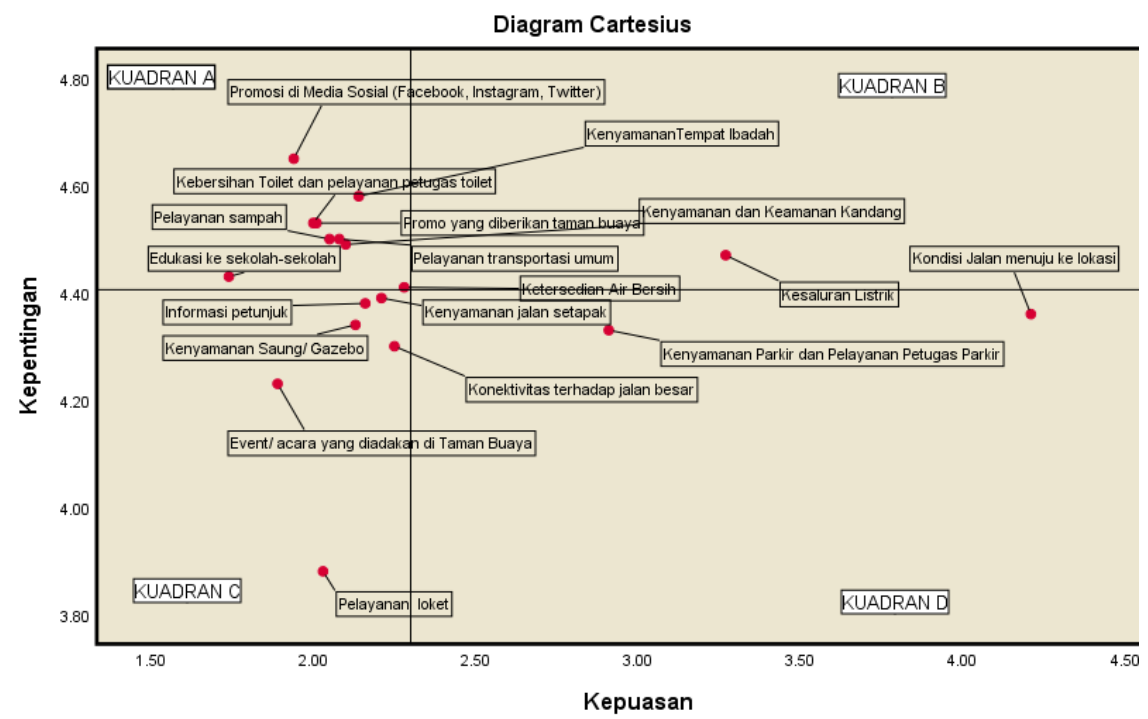

Gambar 1. Diagram Cartesius hasil Kuisioner

Sumber: Olahan Penulis, 2020

\section{Analisis Strategi Meningkatkan Jumlah Pengujung}

Melalui hasil analisis tersebut, selanjutnya untuk mengetahui analisis strategi meningkatkan jumlah pengunjung yang dapat diaplikasikan terhadap Wisata Taman Buaya Tanjung Pasir penulis membuat analisis SWOT. Dari hasil analisis SWOT dapat diusulkan strategi meningkatkan jumlah pengunjung untuk objek studi Wisata Taman Buaya Tanjung Pasir yaitu sebagai berikut:

a. Melakukan penambahan dan perbaikan fisik fasilitas serta prasarana di dalam Taman Buaya sehingga para pengunjung merasa nyaman dan aman serta identitas baru muncul.

b. Mengusulkan untuk pengadaan trayek angkutan umum baru menuju kawasan wisata Tanjung Pasir dengan bekerja sama dengan pemerintah setempat agar para pengunjung dapat menggunakan kendaraan umum sampai depan Taman Buaya.

c. Membuat program promosi dan event-event untuk menarik wisatawan dan sekaligus membuat taman wisata dapat bersaing dengan tempat wisata lain disekitar.

d. Membangun edukasi untuk pengunjung yang datang agar dapat pengetahuan lebih dari dunia buaya.

\section{KESIMPULAN DAN SARAN}

\section{Kesimpulan}

Berdasarkan hasil keseluruhan penulisan Tugas Akhir mengenai Wisata Taman Buaya Tanjung pasir dalam rangka meningkatkan jumlah pengunjung penulis menyimpulkan dari beberapa hasil analisis dan keinginan konsumen serta rekomendasi penataan fisik. Kesimpulannya bahwa berdasarkan hasil penelitian, Taman Buaya Tanjung Pasir ini memiliki potensi yang besar karena letaknya yang berada di dalam kawasan wisata, ijin pemerintah juga sudah ada dan juga terdapat akomodasi yang baik, aksesibilitas yang baik, namun hanya saja transportasi umum yang belum tersedia dengan baik. Kemudian ada hal yang kurang sehingga pengunjung kurang tertarik mulai dari segi fisik dan kurangnya prmosoi atau pemasaran sehingga pengetahuan pengunjung akan tempat tersebut masih kurang.

\section{Saran}

Taman Buaya memerlukan penataan fisik dan strategi promosi yang baik serta menejemen yang baik dari pihak pengelola. Penataan fisik meliputi konsep taman buaya seperti analisis benchmark, perbaikan fasilitas, perbaikan prasarana dan penambahan aspek hiburan seperti tempat pertunjukan, museum, dan tentunya penambahan toko souvenir untuk meningkatkan 
keuntungan dari produksi yang dibuat berasal dari buaya itu sendiri. Dari strategi promosi harus adanya dorongan dari media sosial, media cetak, dan memberikan potongan harga untuk hari tertentu atau event- event yang ada. Semuanya ini juga dari pendapat atau persepsi konsumen yang telah dirasakan setelah datang ke taman buaya tanjung pasir.

\section{REFERENSI}

Ali, B. S. (2016). Strategi pengembangan fasilitas guna meningkatkan daya tarik minat wisatawan. Daya tarik minat wisatawan di derajat pass (waterpark), 9.

Danisworo, W. M. (2002). Revitalisasi Kawasan Kota, Sebuah Catatan dalam. Pengembangan dan Pemanfaatan Kawasan Kota, 34.

Erasmus. (2011). Key Succes factors in managing the tourist experince at the Klein Karoo National Art Festival.

Martokusumo, W. (2006). Revitalisasi dan Rancangan Kota, Beberapa Catatan dan Konsep Penataan Kawasan Kota Berkelanjutan. Perencanaan Wilayah dan Kota, 17.

Yoeti. (2014). Komponen dasar Pengembangan Pariwisata di Dalam Proses Perencanaan. Undang-Undang no 25 Konsep Perencanaan Pariwisata.

Pemerintah Kabupaten Tangerang. (2017). RKPD KABUPATEN TANGERANG. Evaluasi Hasil Pelaksanaan RKPD Tahun Lalu dan Capaian Kinerja Penyelenggaraan Pemerintah, 5 vol 2.

(2009). Undang-undang no 10 tahun 2009 tentang Wisatawan.

Buaya, C. B. (2016, Juli). https://hohepeli.blogspot.com/2016/07/cara-budidaya-buaya.html.

Fatin, N. (2018, Nov 28). Pengertian Strategi dan Konsepnya. Retrieved from http://seputarpengertian.blogspot.com/2018/11/pengertian-strategi-dankonsepnya.html

Hestanto. (2009). Definisi Pariwisata (indikator, pengembangan, objek dan daya tarik). Retrieved from https://www.hestanto.web.id/definisi-pariwisata-indikatorperkembangan-objek-dan-daya-tarik/

M, H. (2019, Feb). Strategi Pemasaran Pariwisata Agar Tempat Wisata Ramai Dikunjungi. Retrieved from https://netsolmind.com/pemasaran-pariwisata/

Wirajuniarta, R. (2014, Jan 10). Kajian Teori Kepuasan Pengunjung. Retrieved from http://rendywirajuniarta.blogspot.com/2014/01/kepuasan-pengunjung.html 
